\title{
FURTHER STUDIES OF COMPOUNDS EXHIBITING PROLONGED ANTIOESTROGENIC AND ANTIFERTILITY ACTIVITY IN THE MOUSE
}

\author{
C. W. EMMENS AND W. L. GARR \\ Department of Veterinary Physiology, The University of Sydney, \\ Sydney, N.S.W. 2006, Australia
}

(Received 31st May 1972)

Summary. Groups of twenty female QS-strain mice were injected with a single dose of $0,1,3$ or $9 \mathrm{mg}$ of the triarylalkene H-774. Males were introduced 3, 30 or 60 days after injection. Mating was not greatly affected, but very few females mating within the first 23 days after injection became pregnant. At 30 days, fertility varied from $62 \%$ (1-mg dose) to $17 \%$ (9-mg dose) of that in controls. At 60 days, it was substantially back to normal but the numbers/litter were still lower than in controls. In females receiving the same oral doses, fertility was initially as severely affected, but recovery was more rapid.

Further groups of mice were injected with single doses of 0,2 or $5 \mathrm{mg}$ of the closely related compound, $\mathrm{H}-1076$, vaginal smears were taken daily from some, and others were killed at varying periods between 3 and 119 days afterwards. Some were allowed to mate, others were not. In unmated mice, initial responses were oestrogenic in the uterus and vagina, and oestrous cycles were lengthened at first but later reverted to normal. In the uterus, the glands started to enlarge by Day 7 and proceeded to maximal distention by Day 63. Later, they deflated and five out of six uteri appeared normal by Day 119. In the ovaries, follicles appeared normal in size and numbers, but corpora lutea were few and appeared degenerate. Mating was followed by pregnancy after the 2-mg injections in much the same pattern as with $\mathrm{H}-774$, despite the uterine abnormalities, but only three out of eighteen females became pregnant after 5-mg injections. Implantation numbers and weights were affected in some mice.

These results suggest a lack of progesterone, with little effect on oestrogen production, mediated through reduced ovulation rates and reduced production of progesterone from such corpora lutea as were formed. It is postulated that these compounds may inhibit LH release and/or production.

\section{INTRODUGTION}

Emmens (1971) reported that a number of triarylalkene (triarylethylene) derivatives caused refractoriness to oestradiol for several weeks after injection 
in vaginal smear tests in female rats and mice. These compounds also caused complete sterility for up to several weeks when injected in a single dose of $1 \mathrm{mg}$. Mating still occurred, but sometimes at a slower rate than in controls. Daily injections of 5 to $50 \mu \mathrm{g}$ produced similar effects although at $5 \mu \mathrm{g} /$ day, these took several days to develop. Mating was also reduced in total in a 10-day test with $50 \mu \mathrm{g} /$ day. Oral administration was not followed by refractoriness to oestradiol, but did cause a reduction of fertility of up to $85 \%$ compared with controls, without reducing mating frequency.

This paper reports further investigations with two of the compounds concerned; one (H-774) was used for more detailed observations on the duration of sterility, the other (H-1076) for histological and other observations of the effects on the reproductive tract. There was insufficient of either compound for one alone to be used throughout.

\section{MATERIALS AND METHODS}

\section{Experiment 1}

A colony of 480 young adult female QS-strain mice of 25 to $30 \mathrm{~g}$ body weight was divided into twenty-four groups, each of twenty mice. The mice in twelve of these groups received injections and those in the other twelve received oral doses of $\mathrm{H}-774$, which is $1[p-(2 \mathcal{N}, \mathcal{N}$ diethylaminoethoxy)phenyl] $-1,2 \operatorname{di}(p-$ methoxyphenyl)-but-1-ene citrate (cis:trans-62:38, Text-fig. 1). In each half

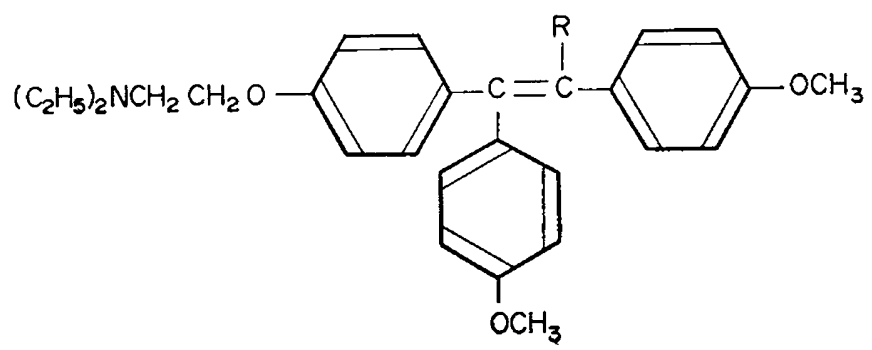

TEXT-Fig. 1. Molecular structure of compounds $\mathrm{H}-774\left(\mathrm{R}=\mathrm{C}_{2} \mathrm{H}_{5}\right)$ and $\mathrm{H}-1076(\mathrm{R}=$ $\left.\mathrm{CH}\left(\mathrm{CH}_{3}\right)_{2}\right)$.

of the experiment, three groups each received a single dose of $0,1,3$ or $9 \mathrm{mg}$ $\mathrm{H}-774$ in $0.05 \mathrm{ml}$ arachis oil by injection or in $0.05 \mathrm{ml}$ of $50 \%$ aqueous propylene glycol orally. Three days later, males were introduced to one group from each dosage level, 30 days later to another set of groups, and 60 days later to a final set. The females were examined daily for vaginal plugs and removed when these were found. Subsequent litter production, sizes and weights were recorded but only the numbers of litters and of mice/litter are discussed here. Thus, the fertility of differently treated groups shortly after treatment and 1 and 2 months after treatment was examined, without the complication of prior exposure to males.

\section{Experiment 2}

A colony of ninety-nine QS females 9 to 11 weeks old, of 25 to $30 \mathrm{~g}$ body weight, was divided into three groups and injected with 0,2 or $5 \mathrm{mg} /$ animal of 
$\mathrm{H}-1076$ in $0.05 \mathrm{ml}$ arachis oil. The compound $\mathrm{H}-1076$ is $1[p-(2 \mathcal{N}, \mathcal{N}$ diethylaminoethoxy)phenyl]-1,2 di(p-methoxyphenyl)-3-methyl-but-1-ene hydrochloride (cis:trans-39:61, Text-fig. 1). Vaginal smears were obtained each day for 110 days from nine mice for each dosage level and three mice from each dosage level were killed on each of Days 3, 7, 21, 42, 63, 84 and 119 after injection (Day 0), leaving nine 'spares'. The ovaries, oviducts, uteri, vaginae and pituitary glands were removed, weighed and placed in Bouin's fixative, processed, and cut into $7-\mu \mathrm{m}$ sections and stained with haematoxylin and eosin.

\section{Experiment 3}

A similar colony of QS females was set up and injected with $\mathrm{H}-1076$ as before, but the females were placed with a fertile male on Days 3, 7, 21, 42, 63 and 84 and vaginal smears were taken daily until plugs were found. These mice were then removed from the rest and killed on Day 10 of pregnancy. The same organs were collected and processed as above, the number of implantation sites also being recorded.

\section{Statistical treatment}

Analyses of variance or covariance were performed after transformation of the data to $\log _{10}$ (organ weight) to equalize variances. The $t$ test was applied, where appropriate, to raw data.

\section{RESULTS}

\section{Experiment 1}

The results of this experiment are shown in Tables 1 to 3 , which give numbers of vaginal plugs found, and consequent litters, from mice injected with or fed $\mathrm{H}-774$ for 3 days, 30 days or 60 days before the introduction of males. Nearly all surviving mice in the experiment eventually mated, but some groups were reduced by deaths. The data are grouped into 10-day periods from the introduction of males.

Table I (males introduced 3 days after treatment) shows little difference in response to different doses of $\mathrm{H}-774$. After injection, mating in some mice was delayed in comparison with controls. This effect is examined below for all results together (Table 4). Fertility was low and all but two of the litters produced came from mice mating after the first 20 days. After oral administration, mating was only delayed in some mice in the group receiving $9 \mathrm{mg}$. It should be noted that mating in the controls receiving injections of vehicle only was somewhat delayed by comparison with the controls fed the vehicle, but only in this particular Table $\left(\chi^{2}{ }_{[1] \text { corr. }}=4.3, P<0 \cdot 05\right)$. Overall fertility after oral dosage was not significantly higher than after injection $\left(\chi_{[1] \text { corr. }}^{2}=2.2, P>0.05\right.$, excluding controls), but all but one litter were produced by mice mating within the first 20 days.

Table 2 (males introduced 30 days after treatment) shows a progressive delay in mating with rising dosage in injected mice, litter production from some early matings, but an overall reduction in fertility of from $62 \%$ of that seen in controls (1-mg dose) to $17 \%$ (9-mg dose). When the compound was administered 


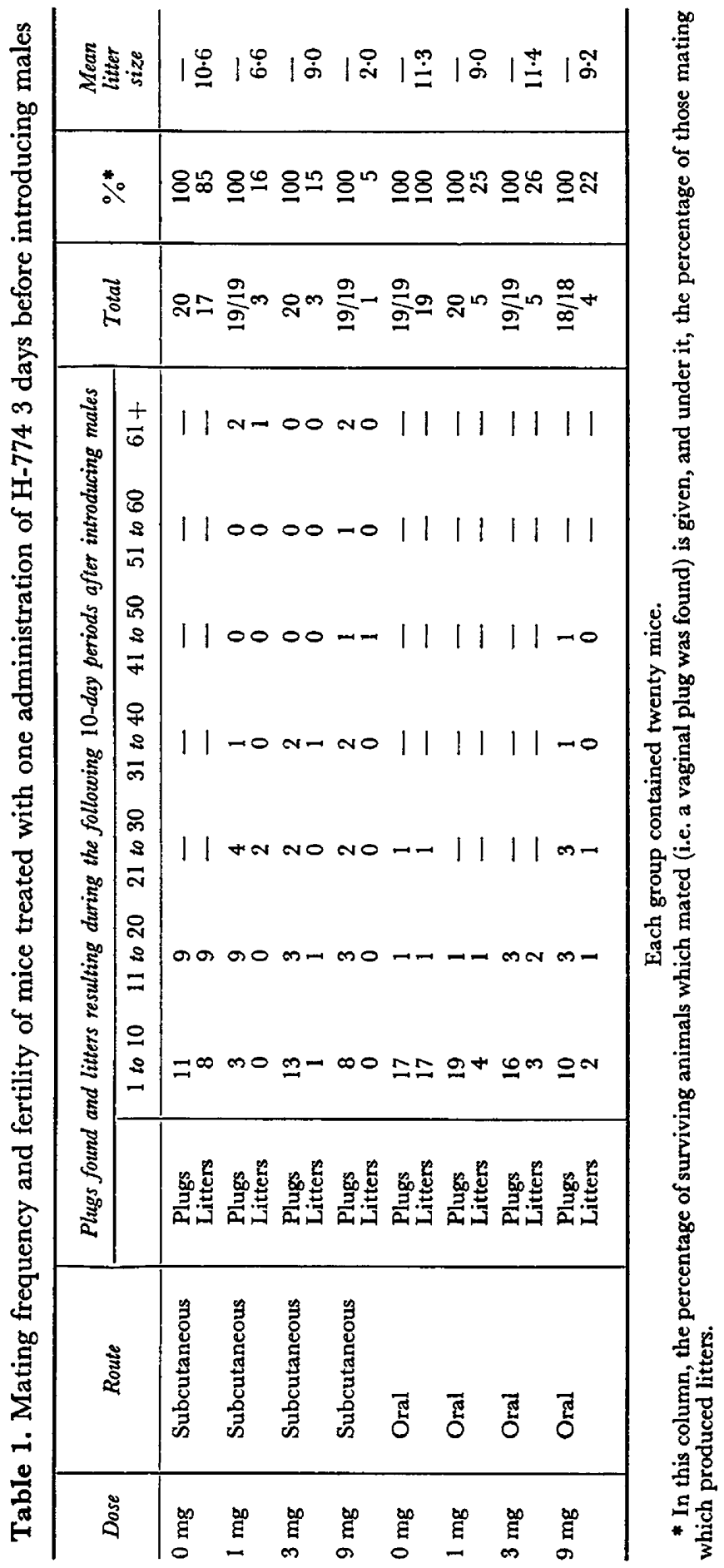




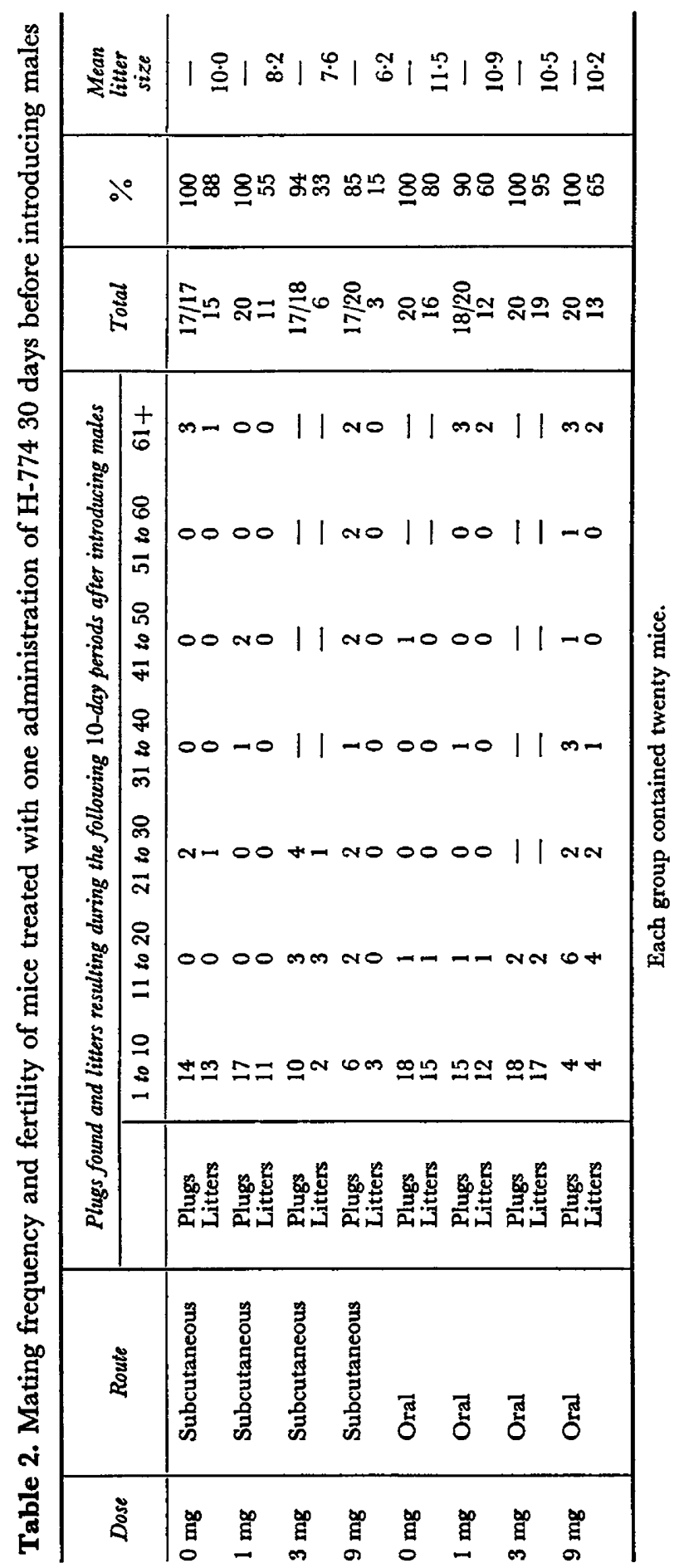




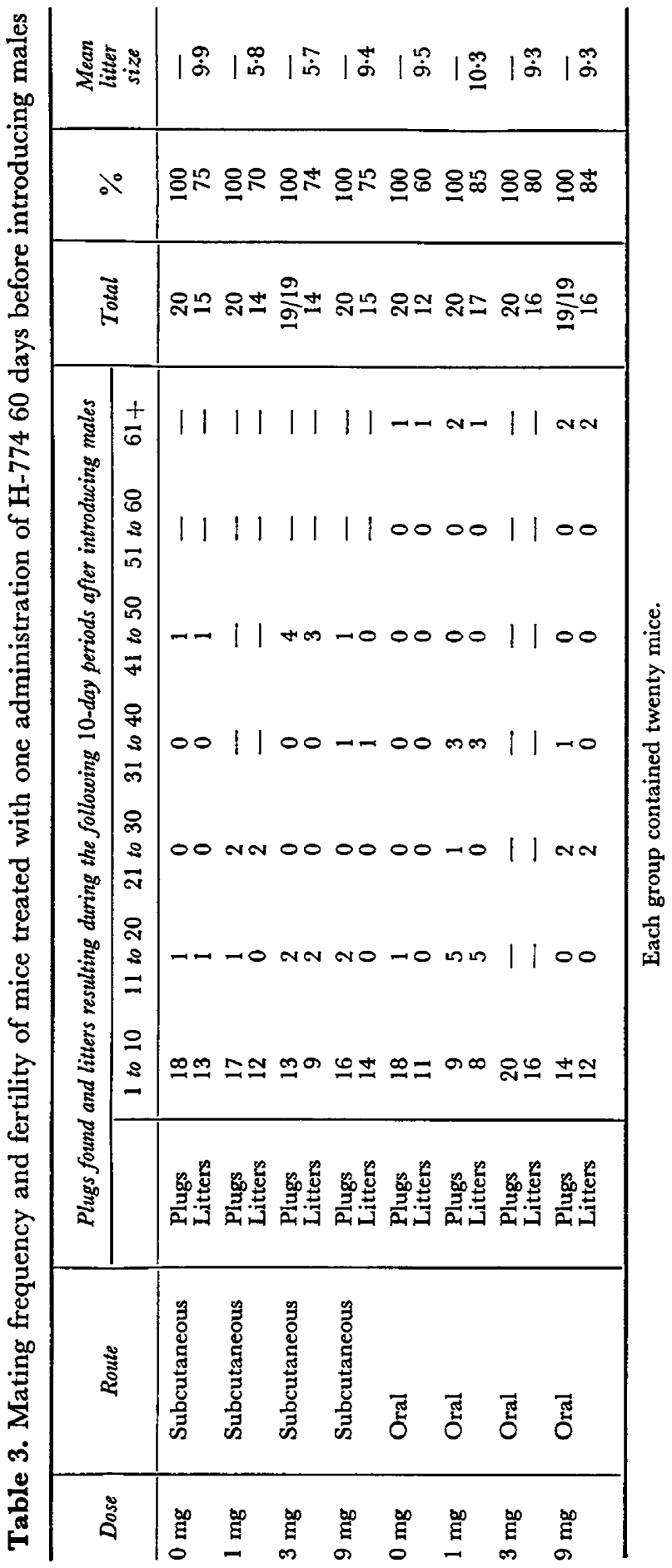


orally, the effects have disappeared, except for a degree of delay in mating, even on the 3-mg dose, which is not apparent from Table 2 but is seen in Table 4 . Although mice receiving $3 \mathrm{mg}$ nearly all mated within 10 days, most of them mated on Day 9 or 10.

Table 3 (males introduced 60 days after treatment) shows a disappearance of all effects by either route of administration except that numbers/litter were still low in two of the injected groups. A suspicion of some delays in mating in comparison with controls is not confirmed by Table 4 or by $\chi^{2}$.

Table 4 presents mean times to mating in all groups, together with the limits of error of these means $(P=0.05)$ calculated from the distributions of log times. These are often quite wide, as mating tended to occur over a considerable period with stragglers up to over 100 days, even occasionally in controls. With such distributions, the modal times to mating were also examined but the differences from the corresponding means turned out to be so small that the modal estimates are not separately presented.

Table 4. Mean times to mating in groups of female mice receiving H-774 3,30 or 60 days before introducing males

\begin{tabular}{|c|c|c|c|c|}
\hline & \multirow{2}{*}{ Schedule } & \multicolumn{3}{|c|}{$\begin{array}{l}\text { Mean no. of days to finding a vaginal plug } \\
\text { (limits of error for } \mathbf{P}=0.05)^{*}\end{array}$} \\
\hline & & 3 days before & 30 days before & 60 days before \\
\hline $\begin{array}{l}0 \mathrm{mg} \\
1 \mathrm{mg} \\
3 \mathrm{mg} \\
9 \mathrm{mg} \\
0 \mathrm{mg} \\
1 \mathrm{mg} \\
3 \mathrm{mg} \\
9 \mathrm{mg}\end{array}$ & $\begin{array}{l}\text { subcutaneous } \\
\text { subcutaneous } \\
\text { subcutaneous } \\
\text { subcutaneous } \\
\text { oral } \\
\text { oral } \\
\text { oral } \\
\text { oral }\end{array}$ & $\begin{array}{l}7.5(4.7 \text { to } 11 \cdot 8) \\
15 \cdot 3(7 \cdot 9 \text { to } 30.0) \\
5 \cdot 6(3 \cdot 2 \text { to } 9 \cdot 9) \\
12.7(6 \cdot 8 \text { to } 23 \cdot 6) \\
3.1(2 \cdot 0 \text { to } 4 \cdot 8) \\
3.2(2 \cdot 3 \text { to } 4 \cdot 5) \\
4.4(2 \cdot 8 \text { to } 6 \cdot 9) \\
8.7(5 \cdot 1 \text { to } 14 \cdot 8)\end{array}$ & $\begin{array}{r}10 \cdot 5(5 \cdot 0 \text { to } 22 \cdot 0) \\
4 \cdot 3(2 \cdot 6 \text { to } 7 \cdot 1) \\
6 \cdot 0(3 \cdot 3 \text { to } 10 \cdot 7) \\
26 \cdot 4(11 \cdot 3 \text { to } 61 \cdot 8) \\
3 \cdot 3(2 \cdot 3 \text { to } 4 \cdot 8) \\
7 \cdot 3(4 \cdot 6 \text { to } 11 \cdot 6) \\
9 \cdot 1(8 \cdot 4 \text { to } 9 \cdot 8) \\
23 \cdot 6(17 \cdot 5 \text { to } 32 \cdot 0)\end{array}$ & $\begin{array}{l}4.5(3.3 \text { to } 5.9) \\
4.8(3.2 \text { to } 7 \cdot 1) \\
6.6(3.7 \text { to } 11.9) \\
3.6(2 \cdot 1 \text { to } 6.2) \\
4.4(2.8 \text { to } 6.8) \\
9.4(5.3 \text { to } 16 \cdot 7) \\
4.0(3.4 \text { to } 4.8) \\
5.5(3.0 \text { to } 10.0)\end{array}$ \\
\hline
\end{tabular}

* Standard errors are not given because the calculations are based on log (dose).

\section{Experiment 2 (unmated mice)}

Vaginal responses. Initial responses as shown by vaginal smears were oestrogenic; all treated mice showed pro-oestrous or oestrous smears within $24 \mathrm{hr}$. By Day 3 after administration, all but one treated animal had or had had a fully cornified smear. The oestrous cycles of the nine mice from which vaginal smears were obtained daily for each dosage level increased in length with increasing dosage initially, but decreased in length as time progressed so that, by Day 110, the cycles in even the high-dose mice were almost as frequent as in the controls (Table 5). The end of a cycle was defined as that point in time at which cornified cells disappeared from the smears from a particular mouse. The longer, atypical cycles were characterized by long periods of predominantly cornified smears, but rarely completely cornified smears.

Sections of vaginae showed no obvious structural changes, other than those characteristic of the oestrous cycle. Wet vaginal weights, equal to those of controls on Day 3 after injection, declined by Day 7 and remained low until Day 63 (Table 6). However, body weight was also lower, particularly in the groups receiving $5 \mathrm{mg}$, and covariance analysis with correction for body weight showed 
no overall drop in vaginal weight that could not be accounted for by bodyweight changes. This does not mean that both were not affected by $\mathrm{H}-1076$, as mean body weights differed significantly between treatments and times.

Uterine responses. Early responses in the uterus were also oestrogenic with an increased luminal diameter and heightening of the luminal and glandular epithelia. The uterine glands began to increase in size by Day 7 and by Day 21,

Table 5. Mean numbers of oestrous cycles completed* per time interval after injection of $\mathrm{H}-1076$ into mice

\begin{tabular}{l|c|c|c|c|c}
\hline \multirow{3}{*}{ Dose } & \multicolumn{5}{|c}{ Interval (days) } \\
\cline { 2 - 6 } & 0 to 22 & 23 to 44 & 45 to 66 & 67 to 88 & 89 to 110 \\
\hline $0 \mathrm{mg}$ & $3.22 \pm 0.22 \dagger$ & $3.22 \pm 0.43$ & $4.22 \pm 0.32$ & $4.11 \pm 0.39$ & $3.33 \pm 0.24$ \\
$2 \mathrm{mg}$ & $0.44 \pm 0.18$ & $1.22 \pm 0.36$ & $2.44 \pm 0.53$ & $2.78 \pm 0.36$ & $3.44 \pm 0.24$ \\
$5 \mathrm{mg}$ & $0.33 \pm 0.24$ & $0.78 \pm 0.22$ & $1 \cdot 78 \pm 0.52$ & $1.78 \pm 0.36$ & $2 \cdot 67 \pm 0.73$ \\
\hline
\end{tabular}

Each group contained nine mice.

* Completion of cycle was taken as the point when cornified cells disappeared from the vaginal smear.

$\dagger$ Standard error of the mean.

Table 6. Mean body weights and mean wet vaginal weights of mice in Experiment 2

\begin{tabular}{|c|c|c|c|c|c|c|}
\hline \multirow{3}{*}{$\begin{array}{c}\text { Time } \\
\text { after } \\
\text { injection }\end{array}$} & \multicolumn{6}{|c|}{ Dose of $H-1076$} \\
\hline & \multicolumn{2}{|c|}{$0 \mathrm{mg}$} & \multicolumn{2}{|c|}{$2 \mathrm{mg}$} & \multicolumn{2}{|c|}{$5 \mathrm{mg}$} \\
\hline & $\begin{array}{l}\text { Body } w t \\
(\mathrm{~g})\end{array}$ & $\begin{array}{l}\text { Vaginal wt } \\
(m g)\end{array}$ & $\begin{array}{l}\text { Body wt } \\
(g)\end{array}$ & $\begin{array}{l}\text { Vaginal wt } \\
(m g)\end{array}$ & $\begin{array}{c}\text { Body wt } \\
(\mathrm{g})\end{array}$ & $\underset{(m g)}{\text { Vaginal wt }}$ \\
\hline $\begin{array}{r}3 \\
7 \\
21 \\
42 \\
63 \\
84 \\
119\end{array}$ & $\begin{array}{c}26 \cdot 8 \\
25 \cdot 8 \\
27 \cdot 7 \\
25 \cdot 5 \\
24 \cdot 8 \\
30 \cdot 7 \\
-\end{array}$ & $\begin{array}{r}79 \cdot 3 \\
72 \cdot 0 \\
84.2 \\
76.7 \\
92 \cdot 7 \\
112.2 \\
86.8\end{array}$ & $\begin{array}{l}27 \cdot 0 \\
24 \cdot 5 \\
28 \cdot 3 \\
29 \cdot 0 \\
28 \cdot 7 \\
29 \cdot 7 \\
-\end{array}$ & $\begin{array}{l}79 \cdot 0 \\
58 \cdot 8^{*} \\
64 \cdot 8^{*} \\
58 \cdot 8^{*} \\
64 \cdot 2 \\
91 \cdot 7 \\
72 \cdot 8\end{array}$ & $\begin{array}{c}23 \cdot 8 \\
22 \cdot 0 \\
25 \cdot 3 \\
24 \cdot 3 \\
28 \cdot 7 \\
30 \cdot 2 \\
-\end{array}$ & $\begin{array}{l}76 \cdot 5 \\
55 \cdot 3^{*} \\
54 \cdot 0^{* *} \\
56 \cdot 0^{* *} \\
56 \cdot 3^{*} \\
66 \cdot 2 \\
82 \cdot 3\end{array}$ \\
\hline Average & & $86 \cdot 3$ & & - & & - \\
\hline
\end{tabular}

Each group contained three mice.

* $P<0.05$ in $t$ test against average of controls.

** $P<0.01$ in $t$ test against average of controls.

they were swollen and filled with fluid, with a decrease in stromal tissue. The myometrium appeared to be unaffected (Pl. 1, Figs a and b). By Day 42, the uteri had large fluid-filled glands with very little stromal tissue (P1. 1, Fig. c), and a maximal effect was seen by Day 63. These phenomena were more regularly and fully developed in the mice receiving $5 \mathrm{mg}$. After Day 63, the glands and lumen deflated, epithelial thickness decreased and stromal tissue replaced the area formerly occupied by the swollen glands (PI. 1, Fig. d). By Day 119, five of the six uteri examined were approaching normal but one was still grossly affected in the 5-mg group. 
PI_ATE 1
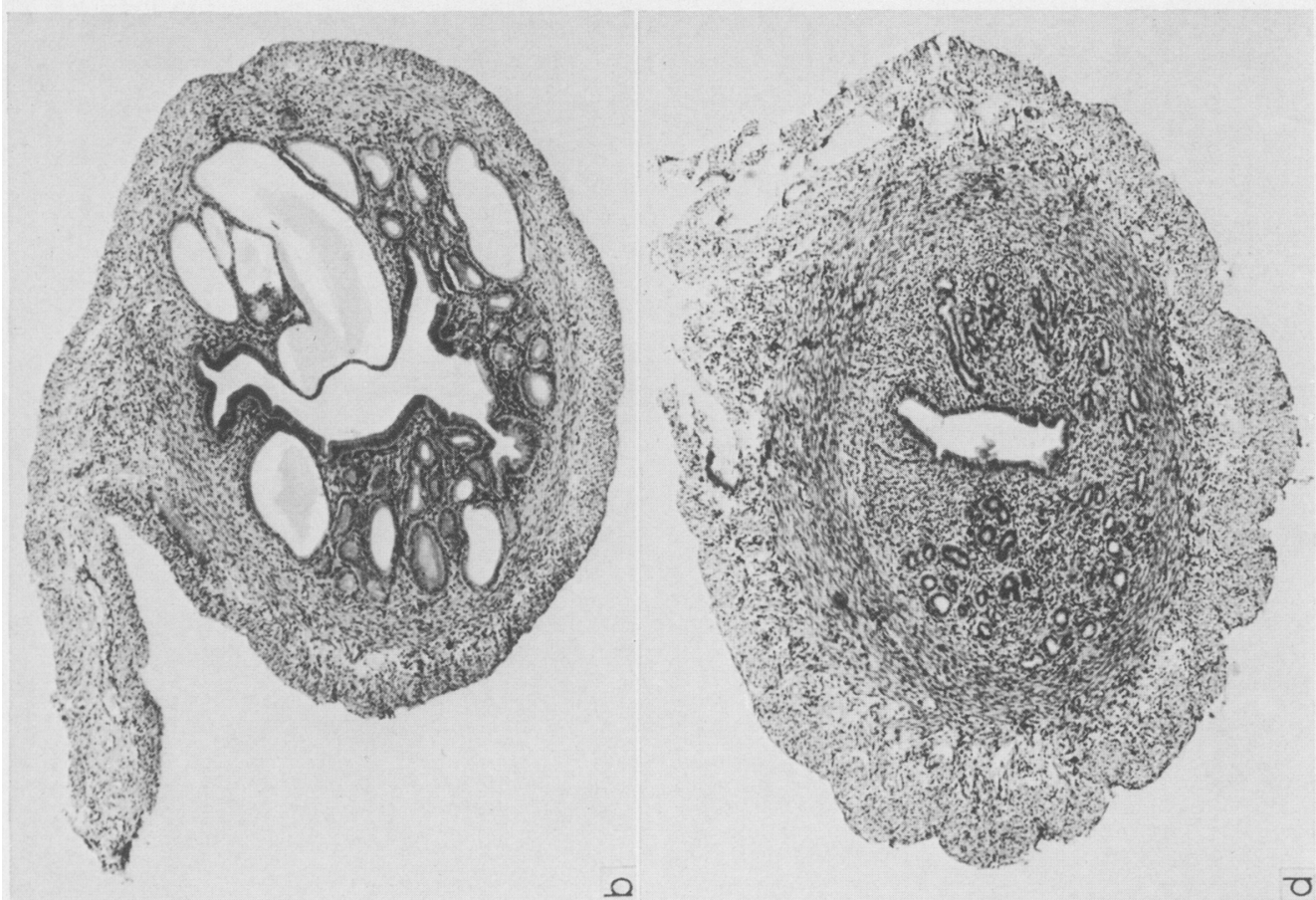

官 字

$\times \times$

के

ฮี

突

त)

తิ

0

它

岀

$5 x$

苛.

L.
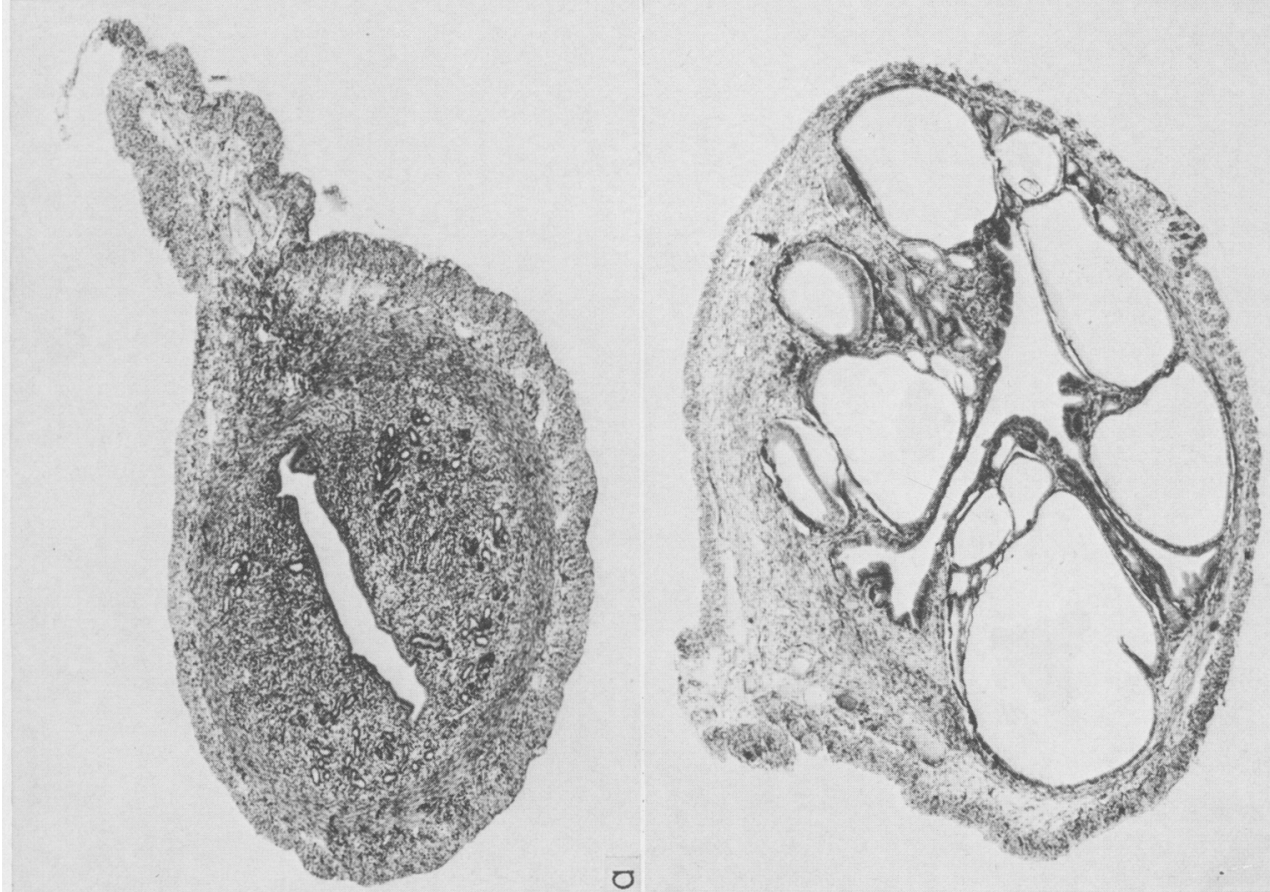

..$\Xi$

密

$-\infty$

远

I

$\therefore$ ช

宫市

कo $x$

$\cong \Xi$

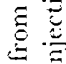

要

$\overrightarrow{0}$

告 宁

总

(Facing p. 36) 
Wet uterine weights in the mice receiving $5 \mathrm{mg}$ were lower on Days 7 and 21 than in the mice receiving $2 \mathrm{mg}$ or in the controls (Table 7), but covariance

Table 7. Mean wet uterine weights of mice in Experiment 2

\begin{tabular}{c|l|l|l}
\hline \multirow{2}{*}{$\begin{array}{c}\text { Time } \\
\text { after } \\
\text { injection } \\
\text { (days) }\end{array}$} & \multicolumn{3}{|c}{ Dose of $H$-1076 } \\
\cline { 2 - 4 } & $0 \mathrm{mg}$ & \multicolumn{1}{|c}{$2 \mathrm{mg}$} & $\mathbf{5 ~ m g}$ \\
\hline 3 & $131 \cdot 7$ & $138 \cdot 3$ & $96 \cdot 2$ \\
7 & $109 \cdot 3$ & $101 \cdot 3 *$ & $71 \cdot 3^{* *}$ \\
21 & $125 \cdot 0$ & $126 \cdot 1$ & $67 \cdot 5^{* *}$ \\
42 & $104 \cdot 7$ & $103 \cdot 7$ & $122 \cdot 5$ \\
63 & $134 \cdot 3$ & $143 \cdot 2$ & $157 \cdot 5$ \\
84 & $147 \cdot 3$ & $155 \cdot 8$ & $101 \cdot 0$ \\
119 & $164 \cdot 0$ (six mice) & $109 \cdot 0$ (four mice) & $106 \cdot 8$ \\
\hline Average & $135 \cdot 3$ & - & - \\
\hline
\end{tabular}
in $\mathrm{mg}$.

Each group contained three mice. Uterine weights expressed

$* P<0.05$ in $t$ test against average of controls.

$* * P<0.01$ in $t$ test against average of controls.

analysis with body weight again showed nothing that could not be accounted for by changes in the latter. The gross glandular inflation certainly did not cause any increase in uterine weight.

Ovarian responses. Effects on the ovary are shown in Table 8, from which it is seen that follicle numbers were unaffected but corpus luteum numbers were

Table 8. Follicle and corpus luteum numbers in unmated mice

\begin{tabular}{|c|c|c|c|c|c|c|}
\hline \multirow{3}{*}{$\begin{array}{c}\text { Day of } \\
\text { treatment }\end{array}$} & \multicolumn{6}{|c|}{ Dose of $H-1076$} \\
\hline & \multicolumn{2}{|c|}{$0 \mathrm{mg}$} & \multicolumn{2}{|c|}{$2 \mathrm{mg}$} & \multicolumn{2}{|c|}{$5 \mathrm{mg}$} \\
\hline & Follicles & Corpora lutea & Follicles & Corpora lutea & Follicles & Corpora lutea \\
\hline $\begin{array}{r}3 \\
7 \\
21 \\
42 \\
63 \\
84 \\
119\end{array}$ & $\begin{array}{c}53 \cdot 6 \pm 1 \cdot 9 \\
46 \cdot 7 \pm 4 \cdot 5 \\
24 \cdot 7 \pm 1 \cdot 6 \\
28 \cdot 0 \pm 3 \cdot 8 \\
41 \cdot 3 \pm 2 \cdot 5 \\
-\end{array}$ & $\begin{array}{l}10 \cdot 3 \pm 0.9 \\
12 \cdot 0 \pm 1 \cdot 0 \\
10 \cdot 0 \pm 1 \cdot 4 \\
22 \cdot 3 \pm 3 \cdot 5 \\
11 \cdot 7 \pm 0 \cdot 8 \\
14 \cdot 0 \pm 2 \cdot 5\end{array}$ & $\begin{array}{c}38 \cdot 3 \pm 1 \cdot 1 \\
48 \cdot 3 \pm 2 \cdot 7 \\
46 \cdot 0 \pm 2 \cdot 4 \\
39 \cdot 7 \pm 2 \cdot 3 \\
31 \cdot 7 \pm 1 \cdot 0 \\
46 \cdot 0 \pm 1 \cdot 6\end{array}$ & $\begin{array}{r}10 \cdot 7 \pm 1 \cdot 5 \\
3 \cdot 7 \pm 0 \cdot 5 \\
3 \cdot 0 \pm 0 \cdot 5 \\
2 \cdot 7 \pm 0 \cdot 8 \\
4 \cdot 3 \pm 0 \cdot 8 \\
6 \cdot 0 \pm 0 \cdot 5 \\
9 \cdot 7 \pm 0.7\end{array}$ & $\begin{array}{c}30.8 \pm 2 \cdot 3 \\
45.0 \pm 5 \cdot 5 \\
36.0 \pm 1.5 \\
18.0 \pm 1.7 \\
27 \cdot 7 \pm 1.4 \\
30.0 \pm 1.3 \\
-\end{array}$ & $\begin{array}{c}1 \cdot 3 \pm 0.3 \\
6 \cdot 0 \pm 1 \cdot 0 \\
1 \cdot 0 \pm 0.2 \\
0 \cdot 3 \pm 0.2 \\
3.7 \pm 1 \cdot 2 \\
4 \cdot 0 \pm 0.9 \\
0.0\end{array}$ \\
\hline Average & $40 \cdot 4 \pm 1 \cdot 5$ & $13 \cdot 4 \pm 0.8$ & - & 一 & - & - \\
\hline
\end{tabular}

Follicles counted had a follicular wall of two-cell (or greater) thickness and the number counted of both follicles and corpora lutea was in mid-sections of both ovaries. Each group contained three mice. Values expressed as means \pm S.E.

much lower in treated animals. Moreover, such corpora lutea as were present appeared old and degenerate. Ovary weights were not affected.

Pituitary responses. Pituitary weights and structure did not appear to be affected, but detailed examination of these glands will be made later with a more suitable fixative. 
Experiment 3 (mated mice)

The numbers of mice becoming pregnant after a single mating (as in Exp. 1) are shown in Table 9, together with numbers of implantation sites and estimated mean implantation weights. This estimate was made by subtracting from the uterine weight in the corresponding group from Exp. 2 and dividing by the number of implantations.

Table 9. Mean implant number and mean implant weight after administration of $\mathrm{H}-1076$ to mice in Experiment 3

\begin{tabular}{|c|c|c|c|c|c|c|}
\hline \multirow{3}{*}{$\begin{array}{c}\text { Day } \\
\text { males } \\
\text { were } \\
\text { introduced }\end{array}$} & \multicolumn{6}{|c|}{ Dose of $H-1076$} \\
\hline & \multicolumn{2}{|c|}{$0 \mathrm{mg}$} & \multicolumn{2}{|c|}{$2 m g$} & \multicolumn{2}{|c|}{$5 \mathrm{mg}$} \\
\hline & $\begin{array}{l}\text { No. of } \\
\text { implants }\end{array}$ & $\begin{array}{c}\text { Implant } \\
w t \\
(m g)\end{array}$ & $\begin{array}{l}\text { No. of } \\
\text { implants }\end{array}$ & $\begin{array}{c}\text { Implant } \\
w t \\
(m g)\end{array}$ & $\begin{array}{c}\text { No. of } \\
\text { implants }\end{array}$ & $\begin{array}{c}\text { Implant } \\
w t \\
(m g)\end{array}$ \\
\hline $\begin{array}{r}3 \\
7 \\
21 \\
42 \\
63 \\
84\end{array}$ & $\begin{array}{l}10 \cdot 0(1) \\
10.7(3) \\
11 \cdot 0(2) \\
12.3(3) \\
14.5(2) \\
12.7(3)\end{array}$ & $\begin{array}{l}40 \cdot 9 \\
61 \cdot 4 \\
54 \cdot 7 \\
55 \cdot 5 \\
77 \cdot 6 \\
-\end{array}$ & $\begin{array}{r}\overline{14 \cdot 0}(1) \\
8 \cdot 3(3) \\
8 \cdot 0(3) \\
7 \cdot 0(2) \\
12 \cdot 0(2)\end{array}$ & $\begin{array}{l}\overline{53 \cdot 9} \\
21 \cdot 5 \\
54 \cdot 2 \\
31 \cdot 8 \\
-\end{array}$ & $\begin{array}{c}2(1) \\
- \\
\overline{14(1)} \\
5(1)\end{array}$ & $\begin{array}{c}22 \cdot 0 \\
- \\
\overline{60 \cdot 4} \\
26 \cdot 6\end{array}$ \\
\hline Average & $11 \cdot 9$ & $59 \cdot 7$ & $10 \cdot 0$ & $40 \cdot 4$ & $7 \cdot 0$ & $36 \cdot 3$ \\
\hline
\end{tabular}

Each group contained three mice. The number of pregnant mice is given in parentheses beside each implant number.

Table 10. Total corpora lutea/mouse from Experiment 3

\begin{tabular}{|c|c|c|c|c|c|c|}
\hline \multirow{3}{*}{$\begin{array}{c}\text { Day } \\
\text { males } \\
\text { were } \\
\text { introduced }\end{array}$} & \multicolumn{6}{|c|}{ Dose of $H-1076$} \\
\hline & \multicolumn{2}{|c|}{$0 \mathrm{mg}$} & \multicolumn{2}{|c|}{$2 m g$} & \multicolumn{2}{|c|}{$5 \mathrm{mg}$} \\
\hline & Pregnant & Non-pregnant & Pregnant & Non-pregnant & Pregnant & Non-pregnant \\
\hline $\begin{array}{r}3 \\
7 \\
21 \\
42 \\
63 \\
84\end{array}$ & $\begin{array}{l}10.0(1) \\
10.0(3) \\
11.5(2) \\
12.7(3) \\
21.0(2) \\
13.7(3)\end{array}$ & $\begin{array}{c}14 \cdot 0(2) \\
18 \cdot \overline{0}(1) \\
12 \cdot \overline{0}(1) \\
\end{array}$ & $\begin{array}{l}19 \cdot \overline{0}(1) \\
14 \cdot 3(3) \\
19 \cdot 0(3) \\
11 \cdot 0(2) \\
14.5(2)\end{array}$ & $\begin{array}{c}10 \cdot 0(3) \\
25 \cdot 0(2) \\
- \\
10 . \overline{0}(1) \\
22 \cdot 0(1)\end{array}$ & $\begin{array}{c}21 \cdot 0(1) \\
- \\
- \\
18.0(1) \\
9.0(1)\end{array}$ & $\begin{array}{l}5 \cdot 0(2) \\
5 \cdot 0(1)^{*} \\
9 \cdot 0(3) \\
3 \cdot 7(3) \\
9 \cdot 0(2) \\
3.5(2)\end{array}$ \\
\hline
\end{tabular}

The numbers of mice are given in parentheses.

* Two sets of ovaries missing.

Although the figures from treated mice are irregular, it is apparent from Table 9 that pregnancy was by no means inhibited by the gross abnormalities seen in the uterus up to Day 63 or longer, particularly in the lower-dosage groups. Those mice which became pregnant did not show any particularly abnormal external uterine symptoms, but their internal appearance has yet to be checked. This result accords with those in Exp. 1. Mating was delayed in most groups in comparison with controls, but the numbers are too small for any firm conclusions, and those in Exp. 1, although with a different compound, are far more reliable. 
Compound H-1076 thus had an antifertility effect in that it decreased the numbers of mice becoming pregnant, the number of implantations in some of those which became pregnant, and the implantation weights.

Table 10 shows the numbers of corpora lutea in mated mice becoming pregnant, in contrast to those in mice not pregnant, from which it is apparent that, with few exceptions, the pregnant treated animals had as high a count as pregnant controls. It seems that the poor ovulation rate commented on in Exp. 2 could account for part, at least, of the lowered fertility in treated animals.

\section{DISGUSSION}

There seem to be few references in the literature with which to compare the data in Tables 1 to 4, dealing with the duration of action of H-774 as an antifertility agent in Exp. 1. Even in a dosage of $9 \mathrm{mg}$, it would seem to be of low toxicity, with some effect on body weight, but no greater mortality over the test period than in controls (four deaths in both treated and controls in a total of 120 mice each). At this dosage, it happened that mice showed no residual effects on fertility when males were introduced 60 days after treatment, although lower dose rates did produce some depression in litter size in injected mice, indicating that the group receiving $9 \mathrm{mg}$ exhibited a rather more favourable recovery rate than might have been expected from the rest of the data.

Dosage groups receiving $1 \mathrm{mg}$ or $3 \mathrm{mg}$ by injection were recovering fertility by 30 days, as judged by the numbers of litters produced and the numbers of young/litter, although this recovery was not complete by 60 days, as noted above. After oral dosage, however, the effects had gone by 30 days, as judged by the same criteria.

The results of Exp. 2, showing a peak of effect on glandular enlargement with high dose rates at 60 days, would, without those of Exp. 3, lead to a conclusion that despite their structural likeness, H-774 and H-1076 must differ in action or duration of action. Experiment 3 makes it clear, however, that although the uteri of unmated mice presented an appearance suggesting complete sterility, implantation was in fact possible. Uteri in the early implantation stages have yet to be examined histologically, but their external appearance does not suggest anything very abnormal.

The responses studied in Exps 2 and 3 appear to be unique. The only similar response is to oestrogen administration, when uterine glands inflate to give the 'Swiss cheese' hyperplasia of Parkes (1935) in ovariectomized mice, but oestrogen treatment was not continued beyond 18 days in Parkes' experiments. Others have induced similar effects in guinea-pigs (Burch, Wolfe \& Cunningham, 1932), chimpanzees (Zuckerman \& Morse, 1935) and women (Kaufman, 1934).

Selye, Thomson \& Collip (1935) and McEuen, Selye \& Collip (1936) have shown that dosage of up to 10 weeks' duration in ovariectomized rats with 30 to $60 \mu \mathrm{g}$ oestrone intraperitoneally or subcutaneously causes metaplasia and a stratified squamous epithelium to develop with uterine cornification, a type of response not seen here. This effect is prevented in rats and guinea-pigs by progesterone (Dessau, 1937; Korenchevsky \& Hall, 1938). 
The decreased numbers and degenerate appearance of the corpora lutea in treated mice suggest decreased progesterone output. The unchanged follicle counts and appearance suggest that oestrogen output is not affected. The effects observed in the reproductive tract may thus be due to decreased progesterone plus some direct actions of $\mathbf{H}-1076$, the latter accounting for the differences in appearance of the uteri from those exposed to an excess of oestrogen alone. Indirect actions of $\mathrm{H}-1076$, such as decreased $\mathrm{LH}$ output due to effects on the hypothalamus or pituitary, may account for the effects on the corpora lutea. The effects of simultaneous administration of progesterone are under examination.

\section{ACKNOWLEDGMENTS}

This work was supported by grants from the Ford Foundation and the Australian Research Grants Committee. We are also indebted to Professor E. G. Amoroso for helpful criticism and suggestions.

\section{REFERENGES}

Burch, J. G., Wolfe, J. M. \& Gunningham, R. S. (1932) Experiments on endometrial hyperplasia. Endocrinology, 16, 541.

Dessau, F. (1937) Chronische Wirkungen oestrogener Stoffe am Meerschweinenuterus. Archs int. Pharmacodyn. Ther. 55, 402.

Emmens, C. W. (1971) Compounds exhibiting prolonged antioestrogenic and antifertility activity in mice and rats. 7. Reprod. Fert. 26, 175.

Kaufman, C. (1934) Therapeutics with hormones of the ovary. Proc. R. Soc. Med. 27, 849.

Korenchevsky, V. \& HaLl, K. (1938) The effect of progesterone on the metaplasia of the uterine epithelium of rats injected with oestrogens. 7. Obstet. Gynaec. Br. Emp. 45, 22.

MaEuen, C. S., Selye, H. \& Collip, J. B. (1936) Some effects of prolonged administration of oestrin in rats. Lancet, $\mathbf{i}, 775$.

PARkes, A. S. (1935) Experimental endometrial hyperplasia. Lancet, $i, 485$.

Selye, H., Thomson, D. L. \& Collip, J. B. (1935) Metaplasia of uterine epithelium produced by chronic oestrone administration. Nature, Lond. 135, 65.

ZuCKerman, S. \& MoRse, A. H. (1935) The experimental production of excessive endometrial hyperplasia. Surgery Gynec. Obstet. 61, 15. 